\title{
Penyuluhan Alat Deteksi Kesadahan Dalam Air Berbasis Light Dependent Resistor Di Kelurahan Giritontro, Kecamatan Giritontro, Kabupaten Wonogiri
}

\section{Workshop On Detector of Water Hardness Based On Light Dependet Resistor In Giritontro Village, Giritontro District, Wonogiri Regency}

\author{
Sumarna $^{1}$, Dyah Kurniawati Agustikasa* ${ }^{1}$, Agus Purwanto ${ }^{1}$, Nur Kadarisman ${ }^{1}$, \\ Anggiyani Ratnaningtyas Eka Nugraheni ${ }^{2}$, Dina $^{2}$ \\ ${ }^{1}$ Jurusan Pendidikan Fisika, Universitas Negeri Yogyakarta, Jl. Colombo No. 1, Yogyakarta \\ ${ }^{2}$ Jurusan Pendidikan Kimia, Universitas Negeri Yogyakarta, Jl. Colombo No. 1, Yogyakarta \\ *E-mail: dyah_kurniawati@uny.ac.id
}

\begin{abstract}
Abstrak
Beberapa daerah di Wonogiri memiliki tanah yang mengandung kapur, sementara itu sebagian masyarakat mengonsumsi air yang berasal dari dalam tanah. Pada kegiatan pengabdian kepada masyarakat tahun 2016 ditemukan permasalahan dalam masyarakat di kelurahan Wonogiri yaitu sulitnya mendeteksi adanya kapur dalam air yang mereka konsumsi. Sebagai akibatnya banyak masyarakat yang menderita penyakit dalam yang diakibatkan pengendapan kapur di dalam tubuh mereka seperti penyakit ginjal. Oleh karenanya, tim PPM Fakultas MIPA Universitas Negeri Yogyakarta membangun sistem pendeteksi adanya kapur dalam cairan berbasis Light Emitting Diode (LED) dan Light Dependent Resistor (LDR). LED digunakan untuk menyinari cairan dengan kadar kapur yang berbeda-beda, kemudian LDR akan mendeteksi cahaya LED yang melewati cairan tersebut. Besar kecilnya nilai luaran LDR akan bergantung kadar kapur dalam cairan. Masyarakat sangat antusias dan mulai menggunakan alat ini untuk mendeteksi adanya kapur di air yang mereka konsumsi.
\end{abstract}

Kata kunci: Kesadahan, LDR, LED

\begin{abstract}
Some areas in Wonogiri contain hardness in its soil, while some people consume water that come from the soil. In community service activity in 2016, we found problems in the community in Giritontro, Wonogiri that is the difficulties to detect the hardness in the water that people consume. As a result, many people who suffer from internal diseases caused by the deposition of lime in their bodies such as kidney disease. Therefore, the PPM team of the Faculty of Mathematics and Natural Sciences of Yogyakarta State University built a hardness detection system in liquid based Light Emitting Diode (LED) and Light Dependent Resistor (LDR). LEDs are used to irradiate fluids with different lime levels, then LDR will detect the LED light passing through the liquid. The size of the LDR output value will depend on the lime content in the liquid. People are very enthusiastic and start using this tool to detect the presence of limestone in the water they consume.
\end{abstract}

Keywords: Hardness, LDR, LED

\section{PENDAHULUAN}

Air layak minum sudah menajdi langka dalam beberapa tahun terakhir. Bahkan di beberapa tempat air minum yang diambil dari sumur terkontaminasi kapur yang terkandung dalam tanah. Salah satu persyaratan utama air bersih layak minum yang diatur dalam Peraturan Menteri Kesehaan RI No. 492/Menkes/Per/IV/2010 tentang Persyaratan Kualitas Air Minum adalah parameter kesadahan dengan nilai baku mutu sebesar $500 \mathrm{mg} / \mathrm{l}$. Salah satu penyebab utama terjadinya kesadahan 
adalah kandungan $\mathrm{Ca} 2+$ (kesadahan kalsium) atau yang biasa disebut air kapur. Air yang terlalu banyak mengandung kapur biasanya bersifat basa, padahal menurut standar baku mutu air yang berlaku, air minum tidak boleh mempunyai $\mathrm{Ph}$ lebih dari 8,5 (PMK, 2010)karena berbahaya bagi kesehatan.

Air yang memiliki kadar kapur yang tinggi disebut air sadah atau air dengan kesadahan tinggi dan bisanya diwakili oleh senyawa $\mathrm{Ca}(\mathrm{CO}) 3$ atau adanya ion logam $\mathrm{Ca} 2+$ dan $\mathrm{Mg} 2+$. Air sadah ini dapat menyebabkan beberapa gangguan kesehatan apabila melebihi kadar maksimal yang ditetapkan. Masalah bagi kesehatan terutama dapat menyebabkan penyumbatan pembuluh darah jantung/cardiovascular disease dan batu ginjal/urolithiasis (Dinora dan Purnomo, 2013). Air tanah khususnya di daerah yang memiliki kondisi geologi dengan jenis tanah batuan gamping, mempunyai kesadahan yang tinggi karena air tanah mengalami kontak langsung dengan batuan kapur yang ada.

Berdasarkan hasil kegiatan PPM tahun 2016 berjudul "Pelatihan Biosand Filter Untuk Mengangani Masalah Kesadahan (Kadar Kapur) Dalam Air Minum Bagi Masyarakat Kelurahan Giritontro, Kabupaten Wonogiri" beberapa masyarakat menyatakan bahwa daerah tempat kegiatan PPM tersebut berlangsung mengalami masalah kadar kapur yang cukup tinggi. Masyarakat khawatir kadar kapur yang tinggi tersebut dapat menyebabkan kualitas kesehatan menurun. Permasalahan yang dihadapi masyarakat adalah sulitnya menentukan adanya kapur pada air yang mereka konsumsi. Deteksi sederhana adanya kapur dalam air yang dikonsumsi oleh masyarakat adalah munculnya kerak berwarna putih pada dinding panci ketika memasak air dan rasa air yang pahit. Masyarakat membutuhkan alat deteksi kesadahan air sederhana yang mudah digunakan dan harganya terjangkau. Air yang mengandung kapur kekeruhannya akan berbeda dengan air bersih. kadar kekeruhan kapur terkadang tidak terlihat secara kasat mata. Oleh karenanya diperlukan alat yang dapat mendeteksi kekeruhan ini. Salah satu cara yang dapat digunakan adalah dengan menyinari air terkontaminasi kapur dengan LED. Setelah itu LDR akan menangkap sinar LED setelah malalui cairan. Nilai yang terbaca pada LDR menunjukkan seberapa keruh cairan tersebut.

LED atau Light Emitting Diode terdiri dari sambungan $\mathrm{p}-\mathrm{n}$ junction. Sifat listrik dasar dari dioda semikonduktor adalah piranti tersebut hanya memungkinkan arus listrik mengalir dalam satu arah. Kebanyakan semikonduktor terbuat dari konduktor yang buruk seperti silikon dan germanium kemudian atom dari bahan lain ditambahkan ke dalamnya. Proses penambahan atom ini disebut doping. Bahan semikonduktor memiliki jumlah elektron terluar empat yang terikat satu sama lain. Proses doping menambahkan atom ekstra dengan elektron yang dapat bergerak dalam material dan dapat meninggalkan bahan. Bahan dengan kelebihan elektron ekstra disebut jenis $\mathrm{N}$, dan bahan dengan defisit elektron (kelebihan hole) disebut jenis P. Sebuah dioda adalah perangkat yang menghubungkan jenis $\mathrm{N}$ dan jenis $\mathrm{P}$. Daerah di mana kedua bahan bertemu disebut sebagai sambungan P-N. Gambar 1 menunjukkan

LED beroperasi ketika diberi bias maju di mana dioda terhubung sehingga arus mengalir.

Kelebihan Elektron bahan jenis $\mathrm{N}$ akan berpindah ke daerah jenis $\mathrm{P}$ yang memiliki kelebihan hole. Elektron akan berekombinasi dengan hole dan akan melepaskan foton dan memancarkan cahaya (Wood, 2009).

Piranti pendeteksi adanya cahaya salah satunya adalah LDR (Light Dependent Resistor) dikenal juga sebagai photoresistor, fotokonduktor atau fotosel, adalah resistor yang naik atau turunnya hambatan tergantung pada jumlah intensitas cahaya. Sebuah LDR dapat memiliki berbagai resistensi dan fungsi. LDR dari bahan semi-konduktor dengan resistensi 
yang tinggi. Alasan resistensinya tinggi adalah bahwa sangat sedikit elektron yang bebas dan mampu bergerak karena mereka terikat pada kisi kristal sehingga sulit bergerak. Ketika cahaya jatuh pada bahan semi konduktor foton cahaya akan diserap dan energi akan ditransfer ke electron sehingga elektron dapat membebaskan diri dari kisi kristal dan dapat menghantarkan listrik dan menurunkan resistensi LDR (www.openobject.org).

\section{SOLUSI/TEKNOLOGI}

Kegiatan ini akan diikuti oleh warga Kelurahan Giritonrtro, menggunakan system community development untuk menjaga keberlangsungan program dengan melibatkan warga RT01/RW02 wilayah Kelurahan Giritontro yang air tanahnya terindikasi mengandung kapur. Kegiatan penyuluhan alat deteksi kesadahan dalam air berbasis LDR ini melibatkan 20 orang warga. Kegiatan dilakukan di 2 (RT) di wilayah Kelurahan Giritontro yang air tanahnya terindikasi mengandung kapur.

Kegiatan ini dimulai dengan survey lapangan untuk pengambilan sampel air untuk diuji kesadahannya di dua titik yang akan dijadikan lokasi kegiatan PPM. Kegiatan dilanjutkan dengan melakukan permohonan izin kepada penanggung jawab wilayah. Setelah lokasi telah ditentukan dan telah diberi izin untuk dapat melakukan kegiatan PPM, tim PPM memulai sosialisasi awal ke tokoh/pemuka desa dan menentukan warga yang akan menjadi peserta program penyuluhan dan pelatihan alat deteksi kesadahan dalam air berbasis LDR.

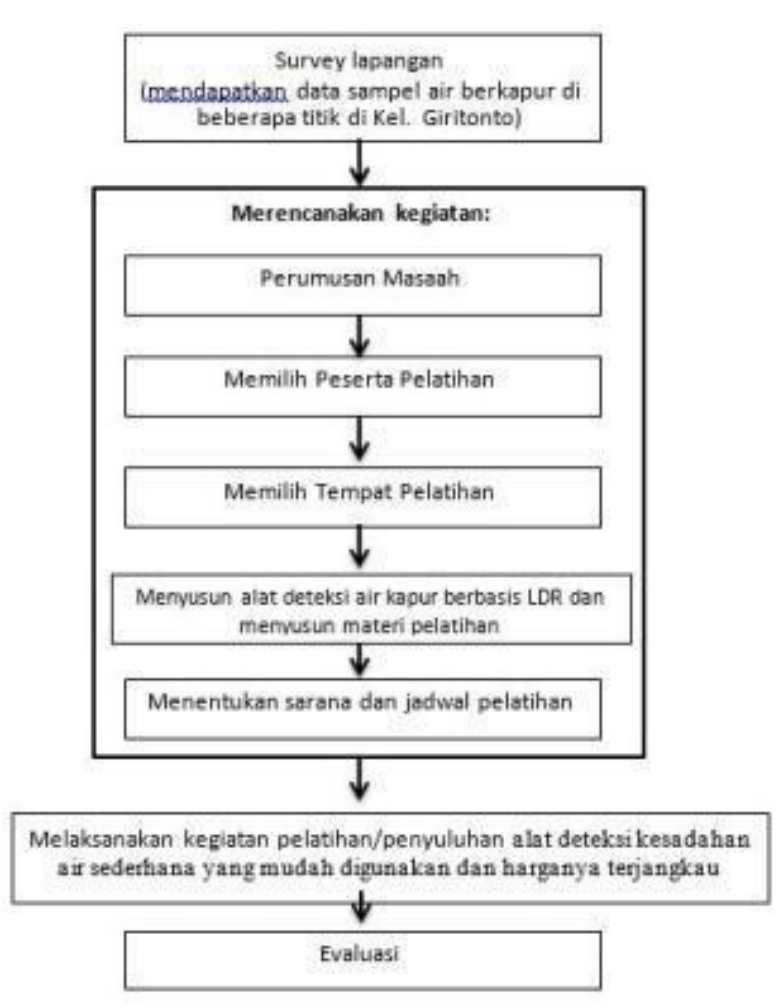

Gambar 1. Flowchart kegiatan PPM

\section{HASIL DAN DISKUSI}

Sebelum membuat alat deteksi kesdadahan air, tim PPM menguji kandungan kapur air sampel dari daerah kelurahan Giritontro, Kabupaten Wonogiri dan didapat nilai kesadahan $127.2 \mathrm{mg} / \mathrm{L}$. Setelah itu kami menyusun peralatan deteksi kesadahan air dan terdiri dari LED dan LDR. Susunan alat dipelihatkan pada Gambar 2 dan produknya diperlihatkan pada Gambar 3.

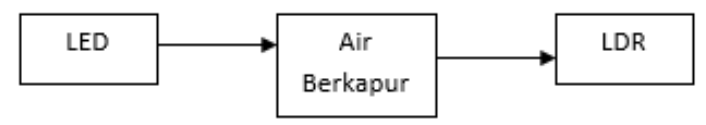

Gambar 2. Skema alat deteksi kesadahan air 


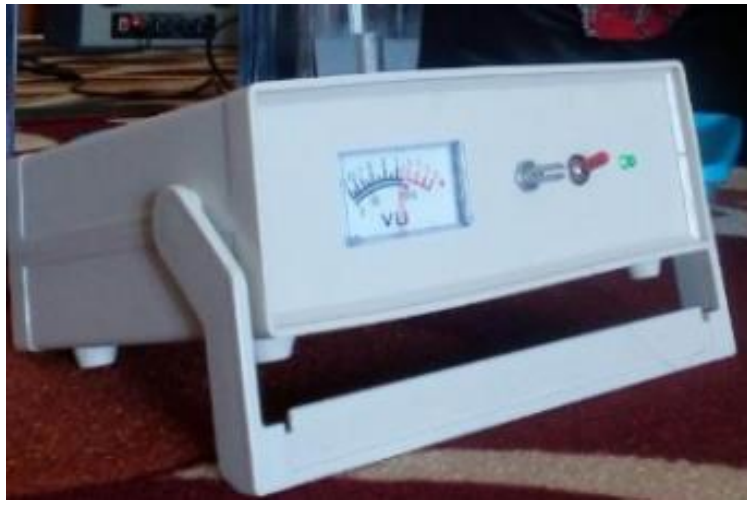

Gambar 3. Alat Deteksi Kesadahan Air

Alat deteksi kesadahan air bekerja dengan cara LED menyinari air berkapur dan sinarmya akan ditangkap oleh LDR. Apabila LED melewati air berkapur nyala LED yang sampai pada LDR akan redup dibandingkan dengan nyala LED saat melewati air tidak berkapur dan lampu indikator akan menyala.

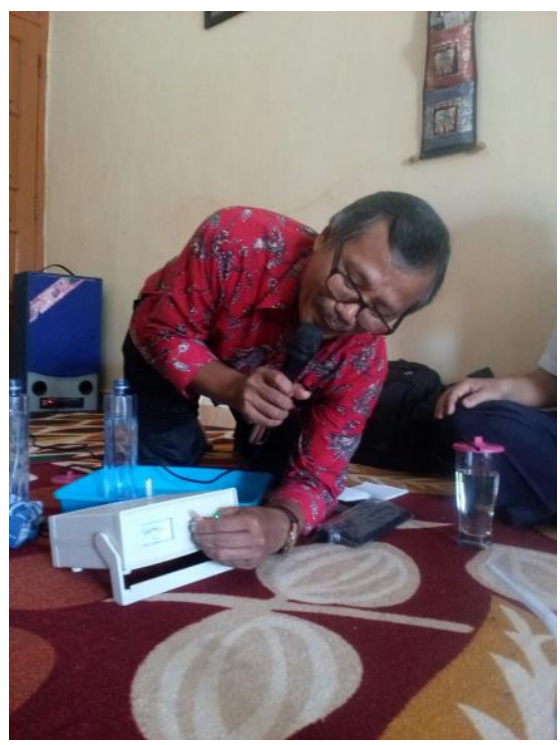

Gambar 4. Pengujian alat deteksi kesadahan air

Alat deteksi kapur diujikan pada saat PPM dan warga sangat antusias. Beberapa pertanyaan yang muncul diantaranya mengenai harga pembuatan dan cara pembuatan. Warga juga menguji langsung alat tersebut. Gambar-gambar pengujian dapat dilihat pada Gambar 4-5.

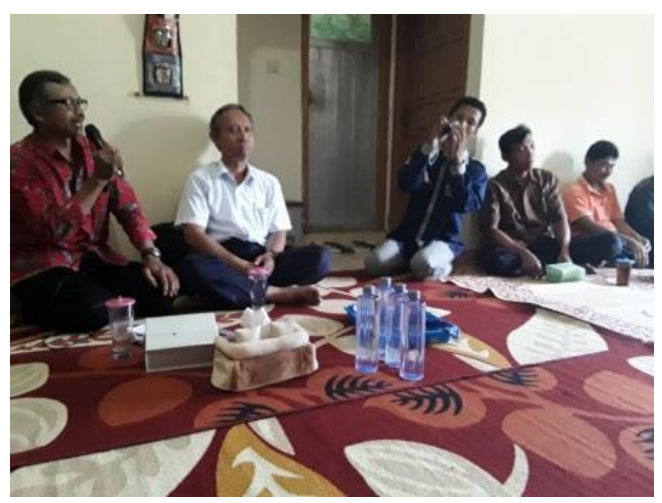

Gambar 5. Pengujian alat deteksi kesadahan air

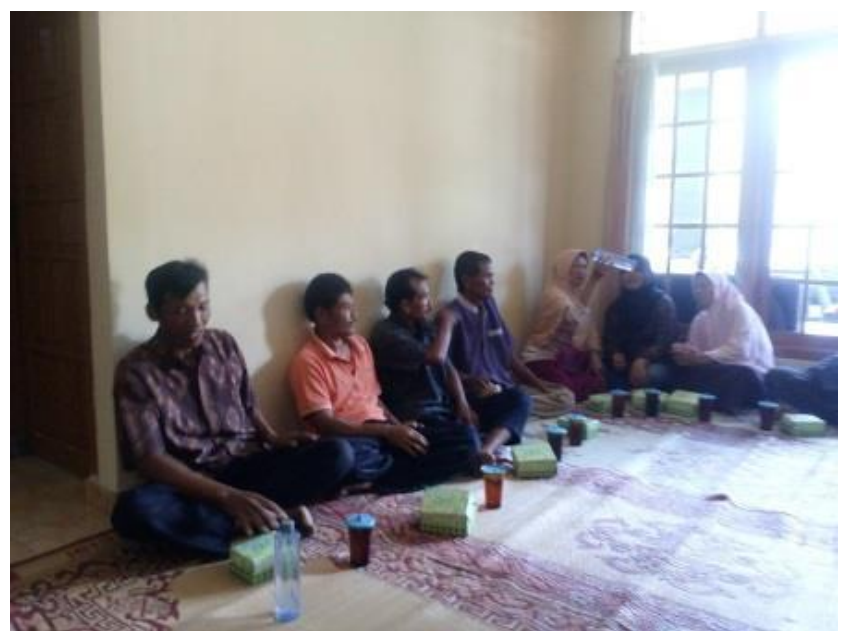

Gambar 6. Antusiasme warga pada saat penyuluhan

Dari hasil penyuluhan didapatkan hasil bahwa warga memberikan respon positif terhadap kegiatan PPM karena selama ini waga sangat membutuhkan alat deteksi kapur pada air yang akan dikonsumsi.

\section{KESIMPULAN}

Masyarakat yang hadir pada kegiatan PPM telah paham mengenai bahaya tingginya kesadahan air untuk kesehatan dan mereka sangat antusias terhadap adanya alat deteksi kesadahan air karena sangat bermanfaat bagi kehidupan mereka. 


\section{UCAPAN TERIMA KASIH}

Ucapan terima kasih disampaikan kepada Fakultas MIPA UNY atas bantuan dana yang diberikan.

\section{PUSTAKA}

Depkes.2008. Katalog Opsi Pengelolaan Air Minum Rumah Tangga. Direktorat Penyehatan Lingkungan. Departemen Kesehatan RI. Jakarta

Depkes. 2009. Strategi Nasional Sanitasi Berbasis Masyarakat. Departemen Kesehatan RI. Jakarta

M.A. Elliot , C.E. Stauber, F. Koksal, F.A. DiGiano, M.D. Sobsey, 2008, "Reductions of E. coli, echovirus type 12 and bacteriophages in an intermittently operated householdscale slow sand filter", Water Research, Vol. 42, pp 2662 - 2670

water" Journal of Chemical Engineering and Materials Science, Vol. 2(10), pp. 156-167
Manahan, Stanley E. 2001. Water Pollution: Fundamentals of Environmental Chemistry. CRC Press LLC. Boca Raton.

Puspitasari B.N., Suliantoro, H., Kusumawardhani, L., 2010,“Analisis Kualitas Pelayanan dengan Menggunakan Integrasi Importance Performance Analysis (IPA) dan Model Kano (Studi Kasus di PT. Perusahaan Air Minum Lyonnaise Jaya Jakarta)", J@ti UNDIP, Vol. V, No. 3, pp. 185-198

Peraturan Menteri Kesehaan RI No. 492/Menkes/Per/IV/2010 tentang Persyaratan Kualitas Air Minum

Said, N., 2008, "Teknologi Pengolahan Air Minum (Teori dan Pengalaman Praktis)", BPPT, Jakarta

Wood, B. Y. M. (2009). How do LEDs work?

www.openobject.org/physicalprogramming/ images/c/cd/Sensor_Report.pdf 